\title{
Oxidation kinetics of Cr-coated zirconium alloy: Effect of coating thickness and microstructure
}

\author{
E.B. Kashkarov ${ }^{\mathrm{a}, *}$, D.V. Sidelev ${ }^{\mathrm{a}}$, M.S. Syrtanov ${ }^{\mathrm{a}}$, C. Tang ${ }^{\mathrm{b}}$, M. Steinbrück ${ }^{\mathrm{b}}$

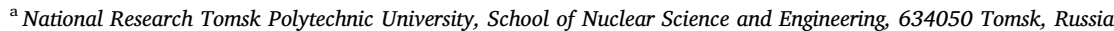 \\ ${ }^{\mathrm{b}}$ Karlsruhe Institute of Technology, Institute for Applied Materials, 76344 Eggenstein-Leopoldshafen, Germany
}

\author{
Keywords: \\ LOCA \\ Steam oxidation \\ Chromium coatings \\ Zirconium alloys \\ Magnetron sputtering \\ Microstructure \\ Hot target sputtering
}

\begin{abstract}
A B S T R A C T
Cr coatings with the thickness of 4.5-9.0 $\mu \mathrm{m}$ and dense/columnar microstructure were deposited onto Zr alloy by cooled or hot target magnetron sputtering. Steam oxidation tests were performed under temperature ramp from 500 to $1200{ }^{\circ} \mathrm{C}$ and isothermal treatment at $9001200{ }^{\circ} \mathrm{C}$ for $1030 \mathrm{~min}$. The measurements of mass gain showed different oxidation kinetics depending on microstructure and thickness of the as-deposited $\mathrm{Cr}$ coatings. The dense microstructure is favorable to prevent alloy oxidation as long as the Cr layer is intact. The higher activation energy of $202 \mathrm{~kJ} / \mathrm{mol}$ is observed for the dense $4.5 \mu \mathrm{m}$-thick $\mathrm{Cr}$ coating while thicker columnar coatings have $177183 \mathrm{~kJ} / \mathrm{mol}$. The time of transition from protective to non-protective behavior increases with coating thickness. It was shown that the $9 \mu \mathrm{m}$-thick $\mathrm{Cr}$ coating with columnar microstructure better protects the zirconium alloy from oxidation at $1200^{\circ} \mathrm{C}$ for $10 \mathrm{~min}$ in comparison with thinner coatings. The fast interdiffusion of $\mathrm{Cr}$ and $\mathrm{Zr}$ at coating/alloy interface significantly affects the oxidation kinetics of Cr-coated zirconium alloy at temperatures above $1100{ }^{\circ} \mathrm{C}$ and long oxidation time.
\end{abstract}

\section{Introduction}

Currently, significant efforts of academia and industry are directed to realize the short term strategy of Accident tolerant fuel (ATF) clad ding for light water nuclear reactors [1 6]. The key approach is to create a protection coating to improve the resistance of zirconium claddings under normal operation $\left(360^{\circ} \mathrm{C}, 18.6 \mathrm{MPa}\right.$, neutron irradia tion), and emergency (in water vapor up to $1200^{\circ} \mathrm{C}$ ) situations. The most severe conditions for nuclear fuel claddings occur in the case of loss of coolant accident (LOCA) with the possibilities towards design extension conditions [7,8]. When the zirconium alloys (E110, E635, Zircaloys, M5, ZIRLO, etc.) interact with water vapor at high tem perature (above $800^{\circ} \mathrm{C}$ ), it leads to $\mathrm{Zr}$ oxidation and embrittlement, and causes release of hydrogen and additional heat in view of exothermic oxidation reaction $\left(\mathrm{Zr}+2 \mathrm{H}_{2} \mathrm{O}=\mathrm{ZrO}_{2}+\mathrm{H}_{2} \uparrow, \Delta \mathrm{H}=-584.5 \mathrm{~kJ} / \mathrm{mol}\right.$ at $\left.1200^{\circ} \mathrm{C}\right)$.

Research performed by various groups worldwide, e.g. at CEA (France), CTU Prague (Czech Republic), JSC "VNIINM" (Russia), MIT (USA), etc.) as well as our previous results [9 16] have shown that chromium is one of the most suitable candidates among the considered materials for protective coating. The $\mathrm{Cr}$ coatings have a reasonable cross section of neutron capture ( $\sim 3.03 .2$ barn), low hydrogen per meability, high corrosion and radiation resistance, good adhesion and wear resistance, small difference in thermal expansion coefficients $\left((6.210 .2) \times 10^{-6} 1 / \mathrm{K}\right)$ in comparison with zirconium ((5.7 9.3) $\left.\times 10^{-6} 1 / \mathrm{K}\right)$ from room temperature to $1000^{\circ} \mathrm{C}$. Among the coating techniques, magnetron sputtering systems have many favour able parameters $[17,18]$ :

high coating purity;

wide range of operation characteristics (target power density of $10-50 \mathrm{~W} / \mathrm{cm}^{2}$, bias potential up to $2-3 \mathrm{kV}$, work pressure $\sim 0.01-1 \mathrm{~Pa}$ );

pulse parameters of power supplies (duty cycle $\sim 0.05-1$, peak current and power density up to $35 \mathrm{~A} / \mathrm{cm}^{2}$ and $5-10 \mathrm{~kW} / \mathrm{cm}^{2}$, etc.);

low thermal flux $\left(0.1-1 \mathrm{~W} / \mathrm{cm}^{2}\right)$ onto substrate during coating deposition.

These parameters can be used to regulate and control type (neutral or ion) and kinetic energy of deposited particles, crystal structure and microstructure of coating, adhesion, and their functional and mechan ical properties. However, the cylindrical tube geometry of $\mathrm{Zr}$ alloy claddings with the length of $4-6 \mathrm{~m}$ and less than $10 \mathrm{~mm}$ in diameter [19] may be challenging for the PVD coating procedure. Another major aspect is the high number of cladding tubes needed for nuclear reactors

\footnotetext{
* Corresponding author.

E-mail address: egor kashkarov@mail.ru (E.B. Kashkarov).
} 
Table 1

Deposition parameters.

\begin{tabular}{|c|c|c|c|c|c|c|c|}
\hline \# & $Q, \mathrm{~W} / \mathrm{cm}^{2}$ & Magnetron & $t, \min$ & $U_{b}, \mathrm{~V}$ & $j_{s}, \mathrm{~mA} / \mathrm{cm}^{2}$ & $h, \mu \mathrm{m}$ & $T_{\text {sub }},{ }^{\circ} \mathrm{C}$ \\
\hline Cr-4.5 & 31.4 & multi-cathode & 128 & 50 & 3.5 & $4.5 \pm 0.1$ & 330 \\
\hline $\mathrm{Cr}-6$ & 39.5 & with hot target & 20 & & 2.8 & $6.0 \pm 0.2$ & 380 \\
\hline Cr-9 & 39.5 & & 30 & & 2.8 & $9.0 \pm 0.3$ & 440 \\
\hline
\end{tabular}

Note: $Q$ - target power density; $t$ - deposition time; $U_{b}$ - bias potential; $j_{s}$ - ion current density on a substrate; $h$ - coating thickness; $T_{\text {sub }}-$ substrate temperature.

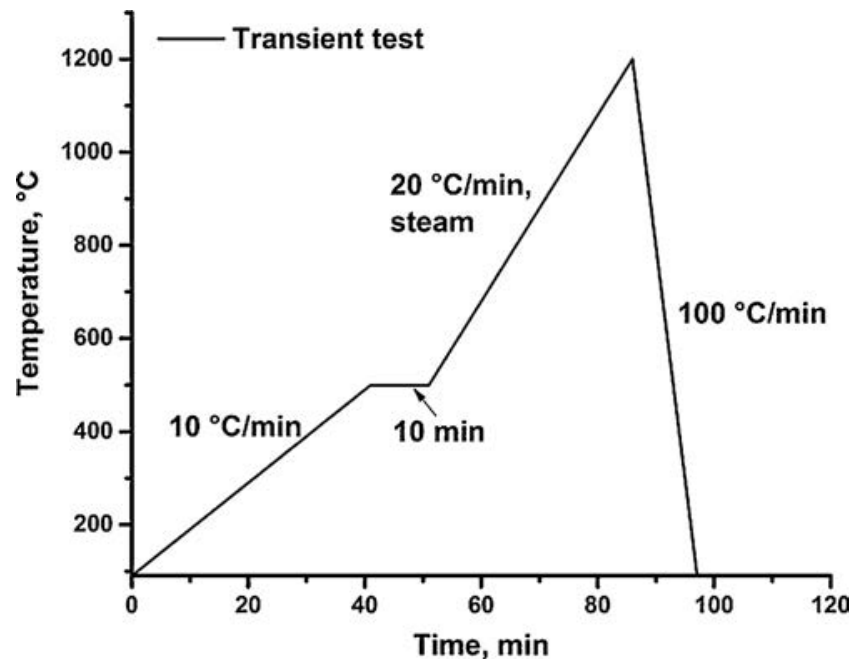

(a)

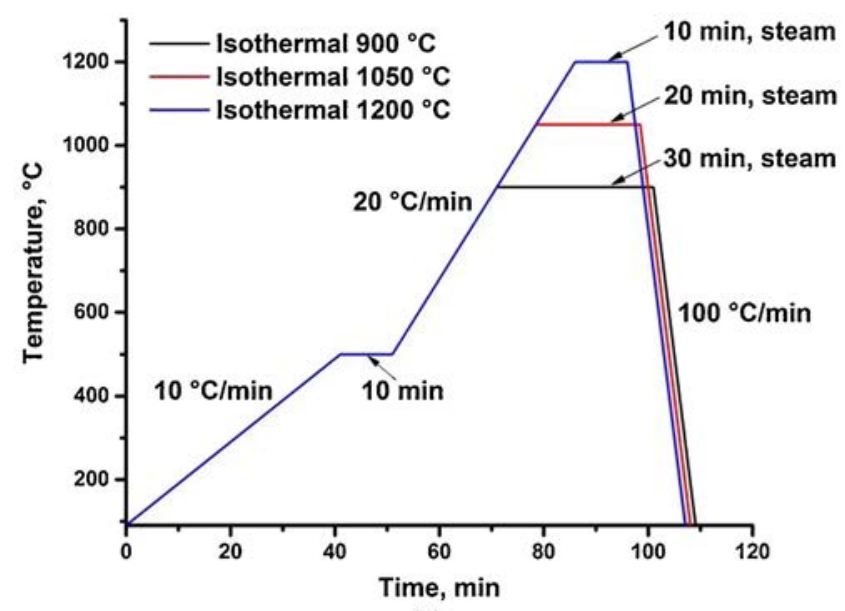

(b)

Fig. 1. Temperature profiles during the transient (a) and isothermal (b) tests. every year (thousands of tubes and more), so the deposition technique should be highly productive and have high repeatability. Thus, new strategies of magnetron sputtering should be considered. Nowadays, the main approach is based on the classical magnetron sputtering, where several linear or cylindrical magnetrons (up to 4-6m) or many short sized magnetrons (e.g. $400 \mathrm{~mm}$ in length) can be applied. The second way is to use the magnetron with hot target that has an ultra high deposition rate $(50 \mathrm{~nm} / \mathrm{s}$ and higher) [20 22]. However, it can sig nificantly influence the coating microstructure and functional proper ties. In the previous article [9], we have shown the role of the de position method on the resistance to high temperature oxidation in air atmosphere at $1100{ }^{\circ} \mathrm{C}$ during $20 \mathrm{~min}$ for $\mathrm{Cr}$ coated $(1.84 .5 \mu \mathrm{m}) \mathrm{Zr}$ $1 \mathrm{Nb}$ alloy. In the present paper, we will carefully consider the influence of deposition conditions on kinetics of zirconium oxidation at LOCA conditions, i.e. during high temperature oxidation in steam atmo sphere. Dense $\mathrm{Cr}$ coatings can be prepared by using of magnetron sputtering with high ion flux onto the substrate [23,24]. On the other hand, thicker $\mathrm{Cr}$ coatings with porous and columnar microstructure can be formed by hot target sputtering with high rates, when deposited particle flux is mainly composed of low energy sublimated particles $[25,26]$.

The aim of the study is to determine the effect of thickness and coating microstructure on oxidation kinetics of $\mathrm{Cr}$ coated zirconium alloy in steam atmosphere. For this, the $\mathrm{Cr}$ coatings with different thickness and microstructure were deposited onto $\mathrm{Zr}$ alloy substrates by classical magnetron sputtering and with hot target. Then, the samples were oxidized in water vapor at 900,1050 and $1200^{\circ} \mathrm{C}$ with measuring their weight and post test examinations of crystal and microstructure.

\section{Materials and methods}

\subsection{Coating deposition}

The chromium coatings were deposited on E110 ( $\mathrm{Zr} 1 \% \mathrm{Nb}$ ) alloy sheets $\left(15 \times 15 \times 2 \mathrm{~mm}^{3}\right)$ and polished Si (110) substrates. The de tailed description of the installation has been reported in the previous work [27]. Chromium targets $\varnothing 90 \mathrm{~mm}$ and thickness of $8 \mathrm{~mm}$; JSC Polema, Russia) with purity of $99.95 \%$ were used. The $4.5 \mu \mathrm{m}$ thick $\mathrm{Cr}$ coating with dense microstructure was obtained by the multi cathode magnetron sputtering system with "closed" $[18,28,29]$ magnetic field and direct current (DC) power supply (Applied Electronics LLC, Russia). The high rate deposition of columnar Cr coatings (thickness of 6 and
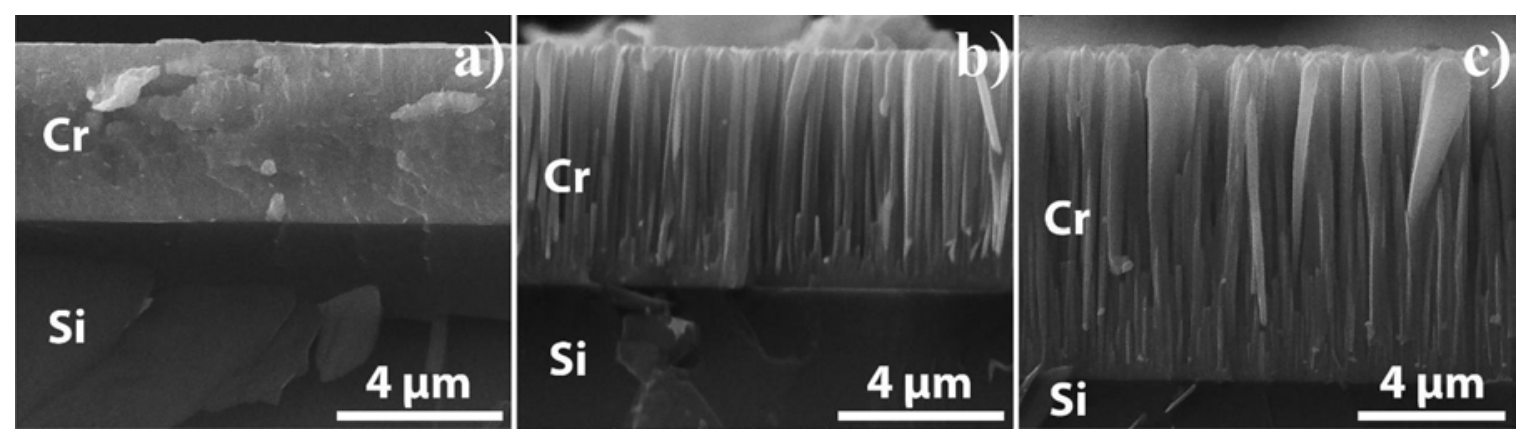

Fig. 2. The SEM images of the as-deposited Cr coatings: Cr-4.5 (a), Cr-6 (b) and Cr-9 (c). 


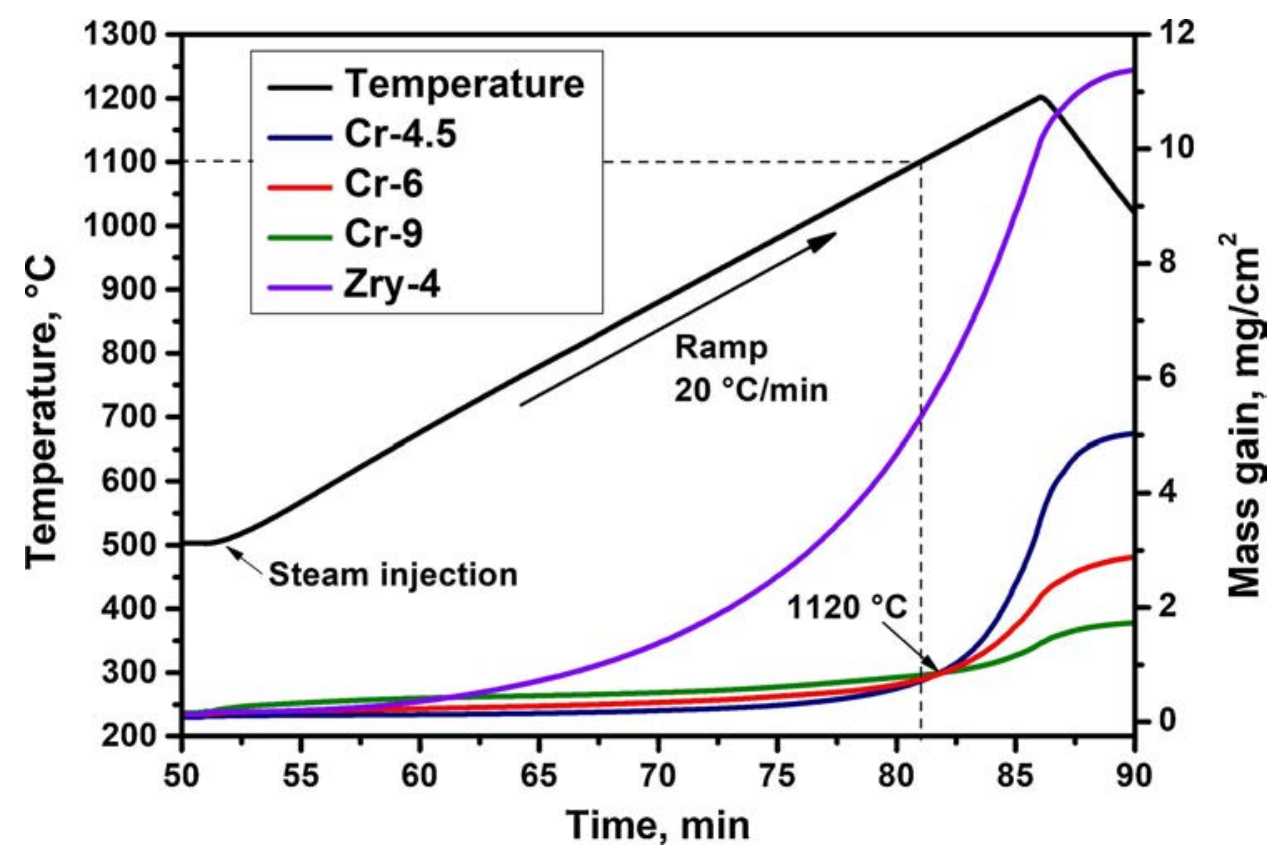

Fig. 3. Mass gain during the transient test of $\mathrm{Cr}$-coated and uncoated zirconium alloys in steam flow at $500-1200{ }^{\circ} \mathrm{C}$.

$9 \mu \mathrm{m}$ ) was performed by hot target magnetron sputtering with DC power supply.

Prior to coating deposition, the E110 (Zr 1\%Nb) alloy was cut onto small sheets $\left(15 \times 15 \times 2 \mathrm{~mm}^{3}\right)$ and holes with diameter of $\varnothing 1 \mathrm{~mm}$ were drilled in these sheets for their holding during LOCA test. Then, to remove the surface oxides and other impurities, the samples were ad ditionally pretreatment. Firstly, the samples were grinded and polished using SiC sandpapers (P600 $\rightarrow$ P4000), rinsed with $98 \%$ alcohol for $2 \mathrm{~min}$ and dried by compressed air. The samples were fixed in stainless steel holders during coating deposition, thus, a small area of the $\mathrm{Zr}$ sheets $\left(\sim 8-9 \mathrm{~mm}^{2}\right)$ remained uncoated. The distance from the $\mathrm{Cr}$ targets to the substrates during coating deposition was $100 \mathrm{~mm}$. The base pressure in the vacuum chamber was $5 \cdot 10^{-3} \mathrm{~Pa}$. The operation pressure was $0.3 \mathrm{~Pa}(\mathrm{Ar})$. Before deposition, the substrates were etched by $\mathrm{Ar}^{+}$ions at the following parameters: Ar pressure $0.15 \mathrm{~Pa}$, accel eration voltage $2.5 \mathrm{kV}$, ion current $40 \mathrm{~mA}$, treatment time $20 \mathrm{~min}$. All substrates were planetary rotated during etching and deposition processes for uniform coating deposition. No preliminary or additional heating of the samples was carried out, the substrate temperature was measured by an infrared pyrometer Optris CTlaser 3MH1CF4 during coating deposition. Other parameters are shown in Table 1.

\subsection{Oxidation tests}

The oxidation tests were performed using a STA 449 F3 thermo gravimetric (TG) analyzing system (NETZSCH, Germany). Zircaloy 4 (Zry 4; Zr 1.5\%Sn; $15 \times 10 \times 0.65 \mathrm{~mm}^{3}$ ) samples were used as the reference material. Firstly, a transient test was carried out to evaluate oxidation kinetics of the Cr coated E110 alloy and uncoated Zry 4 at high temperatures and to select duration of the isothermal tests. At the transient test, the samples were oxidized at temperature from 500 to $1200{ }^{\circ} \mathrm{C}$ in water steam with the heating rate of $20^{\circ} \mathrm{C} / \mathrm{min}$ (Fig. 1a). Isothermal oxidation tests were performed at 900,1050 and $1200{ }^{\circ} \mathrm{C}$ for 30, 20 and $10 \mathrm{~min}$, respectively (Fig. 1b). For each isothermal test, the temperature was stabilized for $1 \mathrm{~min}$ before injecting the steam flow $(2 \mathrm{~g} / \mathrm{h})$. The samples were heated or cooled in protective Ar with a flow rate of $50 \mathrm{~mL} / \mathrm{min}$ except the steam oxidation stage. The mass gain of the samples during oxidation tests was in situ measured in the TG system. Additionally, the weight of the samples was also measured before and after oxidation tests using an analytical balance (AE 240,
Mettler). In the TG tests, the thermocouple was not in direct contact to the sample. Therefore, the exothermic oxidation reaction between zir conium and steam can cause overheating of the reference Zry 4 sample and results in accelerated oxidation kinetics at the initial stage. It should be less important for $\mathrm{Cr}$ coated samples with lower initial oxi dation rates.

The samples with $\mathrm{Cr}$ films ( $\mathrm{Cr} 4.5$, $\mathrm{Cr} 6$ and $\mathrm{Cr}$ 9) had the uncoated corner, so their mass gain and oxidation kinetics some increased due to rapid oxidation of E110 alloy without protective coating. According to the experimental data, the mass gain of uncoated part $\left(\sim 8-9 \mathrm{~mm}^{2}\right)$ was equal to $\sim 0.41,1.41$ and $2.77 \mathrm{mg}$ at 900,1050 and $1200{ }^{\circ} \mathrm{C}$ for the given samples and oxidation conditions. This should be taken into ac count for considering and comparing with other published results.

\subsection{Post test examinations}

The phase composition of the as deposited and oxidized samples was analysed by X ray diffraction (XRD) using Shimadzu XRD 7000S diffractometer equipped with 1280 channel high speed detector (OneSight, Japan). The XRD analysis was performed in Bragg Brentano geometry using $\mathrm{Cu} \mathrm{K \alpha}$ radiation (1.5410 $\mathrm{\AA}$ wavelength) at $40 \mathrm{kV}$ and $30 \mathrm{~mA}$. The diffraction data were analysed by means of the Sleve + program. The coating thickness, microstructure and elemental composition of the samples were investigated by a scanning electron microscope (SEM) Vega 3 (Tescan, Czech Republic) equipped with energy dispersive $\mathrm{X}$ ray spectroscopy (EDX) attachment. The micro structure of the oxidized samples was also analysed by optical micro scopy using AXIOVERT 200MAT (Zeiss, Göttingen, Germany). The elemental distribution of the samples over depth was investigated by glow discharge optical emission spectroscopy (GDOES) using GD Profiler 2 (HORIBA Scientific, Japan). All post test examinations were performed only for central part of the samples.

\section{Results}

\subsection{The as deposited Cr coatings}

Fig. 2 shows the thickness and microstructure of the as deposited $\mathrm{Cr}$ coatings on $\mathrm{Si}$ substrates. It can be seen that the deposition method strongly affects the coating growth. The dense $\mathrm{Cr}$ coating with an 

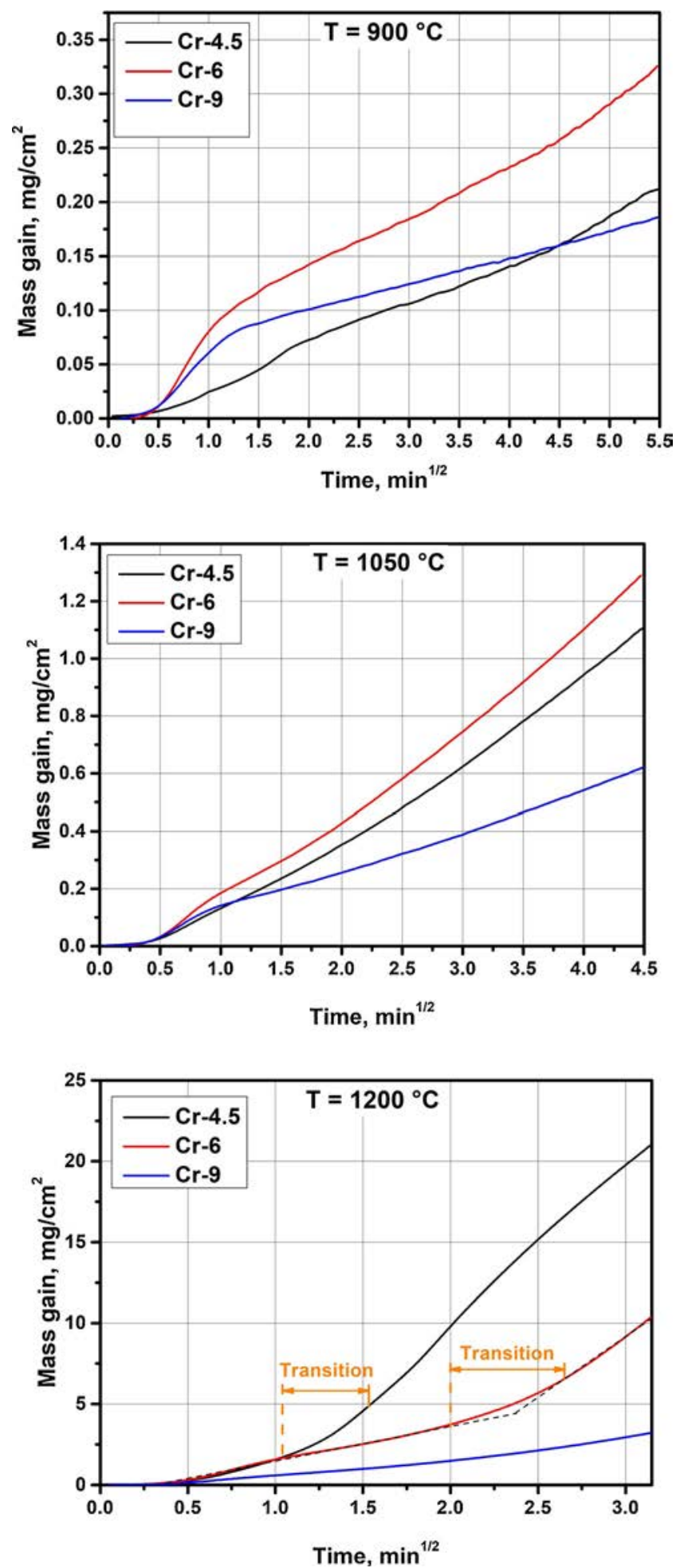

Fig. 4. The mass gain during oxidation of Cr-coated zirconium alloy in steam flow at 900,1050 and $1200^{\circ} \mathrm{C}$.

absolute deposition rate of $6 \mathrm{~nm} / \mathrm{s}$ (i.e. for the unmoved substrate) was deposited by multi cathode magnetron sputtering (Fig. 2a). In this case, energy flux per one deposited atom $(31.2 \mathrm{eV} /$ atom $)$ and ion current density to the substrate $\left(3.5 \mathrm{~mA} / \mathrm{cm}^{2}\right)$ are high enough to cause in tensive surface diffusion and coating densification $[9,23]$. On the other hand, Cr coatings were obtained at high deposition rates $(\sim 50 \mathrm{~nm} / \mathrm{s})$ using hot target sputtering technique (Fig. $2 \mathrm{~b}$ and c). In that case the majority particles were sublimated from hot target and had low $(\sim 0.1 \mathrm{eV})$ kinetic energy [25] in the deposition flux. So, the energy flux per one deposited atom is equal to $\sim 3.2 \mathrm{eV} /$ atom. Thus, porous $\mathrm{Cr}$ coatings are formed with $\mathrm{V}$ shaped columnar grains perpendicular to the substrate surface (zone $\mathrm{T}$ according to the structural zone model (SZM) $[30,31]$ ). Fig. 2b,c show that the column width increases with coating thickness $(6 \rightarrow 9 \mu \mathrm{m})$ due to higher adatom mobility with substrate heating from 380 to $440{ }^{\circ} \mathrm{C}$ at the same deposition rate (see Table 1). Earlier [9], we have shown the influence of deposition rate and energy flux on microstructure for $1.84 .5 \mu \mathrm{m}$ thick $\mathrm{Cr}$ coatings. According to XRD data, the as deposited $\mathrm{Cr}$ coatings have a body cen tered cubic (bcc) crystalline phase with a strong (110) orientation.

\subsection{Transient test at $500-1200^{\circ} \mathrm{C}$}

Fig. 3 shows the TG results of mass gain measured for the $\mathrm{Cr}$ coated E110 alloy and uncoated reference sample during heating in the steam flow at $500-1200^{\circ} \mathrm{C}$. The obtained curves demonstrate that the in tensive oxidation of the uncoated $\mathrm{Zr}$ alloy occurs at $\sim 620^{\circ} \mathrm{C}$ and the mass gain of $11.38 \mathrm{mg} / \mathrm{cm}^{2}$ was reached at $1200^{\circ} \mathrm{C}$. The chromium coatings improve the oxidation resistance of zirconium alloy in steam during temperature ramp. The transition temperature to accelerated oxidation kinetics is increased up to $1050-1100^{\circ} \mathrm{C}$. The sample with the $\mathrm{Cr} 4.5$ coating reveals the lowest rate of mass gain at the initial stage (temperature lower than $1100-1120^{\circ} \mathrm{C}$ ). Then, this sample de monstrates the pronounced rise of mass gain up to $5.03 \mathrm{mg} / \mathrm{cm}^{2}$ at $1200{ }^{\circ} \mathrm{C}$. The samples with $\mathrm{Cr} 6$ and $\mathrm{Cr} 9$ coatings have similar beha vior, but the mass gain is slightly higher at temperatures below $1100^{\circ} \mathrm{C}$. Above $1100^{\circ} \mathrm{C}$, the oxidation kinetics are lower for thicker coatings: the total mass gain was $1.73 \mathrm{mg} / \mathrm{cm}^{2}$ for $9 \mu \mathrm{m}$ thick $\mathrm{Cr}$ coating and $2.88 \mathrm{mg} / \mathrm{cm}^{2}$ for $6 \mu \mathrm{m}$ thick $\mathrm{Cr}$ coating.

\subsection{Isothermal tests at $900-1200^{\circ} \mathrm{C}$}

Fig. 4 shows the TG results during steam oxidation at 900, 1050 and $1200{ }^{\circ} \mathrm{C}$ for the $\mathrm{Cr}$ coated samples. For the temperature range of $900-1050^{\circ} \mathrm{C}$, the columnar coatings demonstrate different oxidation kinetics at the initial stage and continuous oxidation. It can be seen that columnar $\mathrm{Cr}$ films intensively oxidized at the initial stage from the moment of steam injecting up to $1-1.2 \mathrm{~min}$ (at temperatures up to $1050{ }^{\circ} \mathrm{C}$ ). As a result, a protective oxide layer is formed and the oxi dation kinetics slows down significantly. The oxidation behavior of the dense $\mathrm{Cr}$ coating is the same, but the oxidation rate at the initial stage is not much different from further oxidation, i.e. there is no sharp cap turing of oxygen (Fig. 4a and b). Typical parabolic kinetics is observed for $\mathrm{Cr}$ coated samples at 900 and $1050{ }^{\circ} \mathrm{C}$ during the stage of continuous oxidation, while at $1200^{\circ} \mathrm{C}$ the TG curves have a characteristic transi tion from protective to non protective scale (Fig. 4c). This transition is accompanied by an acceleration of oxidation kinetics and defined as the time of transition period marked in Fig. 4c for $\mathrm{Cr} 4.5$ and $\mathrm{Cr} 6$ coatings. For better understanding and comparison of the results, we summarized the mass gain data and the corrosion rates in Table 2. It should be noted that the high mass gains for the reference Zry 4 alloy can be caused by their overheating due to a strong exothermic reaction between zirco nium and steam. Thus, the obtained mass gains exceed approx. two times the values predicted by Cathcart Pawel model and other experi mental data for the steam oxidation at $1200^{\circ} \mathrm{C}[32,33]$.

The corrosion rates of the experimental samples were obtained by fitting the TG curves using the following equation:

$\Delta m=K \cdot t^{n}$

where $\Delta m$ mass gain $\left(\mathrm{mg} / \mathrm{cm}^{2}\right) ; K$ rate constant; $t$ time; $n$ rate exponent (fixed to 0.5 for parabolic kinetics).

It is shown that the $\mathrm{Cr} 4.5$ sample has the lowest mass gain $\left(0.31 \mathrm{mg} / \mathrm{cm}^{2}\right)$ compared to the $\mathrm{Zr}$ alloy with columnar coatings at $900^{\circ} \mathrm{C}$. For higher oxidation temperature $\left(1050^{\circ} \mathrm{C}\right)$, the rate constant of the $\mathrm{Cr} 4.5$ sample is between the rates for columnar coatings ( 6 and 
Table 2

The data of oxidation kinetics for $900-1200{ }^{\circ} \mathrm{C}$.

\begin{tabular}{|c|c|c|c|c|c|}
\hline$T,{ }^{\circ} \mathrm{C}$ & $\#$ & $S, \mathrm{~cm}^{2}$ & $\Delta m(T G A), \mathrm{mg} / \mathrm{cm}^{2}$ & $\begin{array}{l}\Delta m \text { (an. bal.), } \\
\mathrm{mg} / \mathrm{cm}^{2}\end{array}$ & Rate constant, $\mathrm{mg} / \mathrm{cm}^{2} \cdot \mathrm{min}^{1 / 2}$ \\
\hline \multirow[t]{4}{*}{900} & Cr-4.5 (dense, $4.5 \mu \mathrm{m}$ ) & 5.43 & 0.31 & 0.33 & 0.04 \\
\hline & $\mathrm{Cr}-6$ (columnar, $6.0 \mu \mathrm{m})$ & 5.62 & 0.57 & 0.52 & 0.05 \\
\hline & Cr-9 (columnar, $9.0 \mu \mathrm{m})$ & 5.30 & 0.49 & 0.45 & 0.02 \\
\hline & Zry-4 (uncoated) & 3.20 & 4.70 & 4.75 & 1.12 \\
\hline \multirow[t]{4}{*}{1050} & Cr-4.5 (dense, $4.5 \mu \mathrm{m}$ ) & 5.09 & 1.40 & 1.38 & 0.29 \\
\hline & Cr-6 (columnar, $6.0 \mu \mathrm{m})$ & 5.68 & 1.64 & 1.59 & 0.33 \\
\hline & Cr-9 (columnar, $9.0 \mu \mathrm{m})$ & 5.43 & 1.03 & 1.00 & 0.14 \\
\hline & Zry-4 (uncoated) & 3.40 & 16.44 & 16.50 & 3.95 \\
\hline \multirow[t]{4}{*}{1200} & Cr-4.5 (dense, $4.5 \mu \mathrm{m}$ ) & 5.58 & 22.90 & 22.87 & $2.70 / 10.20^{*}$ \\
\hline & $\mathrm{Cr}-6$ (columnar, $6.0 \mu \mathrm{m})$ & 5.67 & 12.61 & 12.59 & $2.09 / 7.80 *$ \\
\hline & Cr-9 (columnar, $9.0 \mu \mathrm{m})$ & 5.35 & 4.13 & 4.09 & 1.12 \\
\hline & Zry-4 (uncoated) & 3.40 & 32.50 & 32.59 & - \\
\hline
\end{tabular}

* Rate constant after transition from protective to non-protective scale.
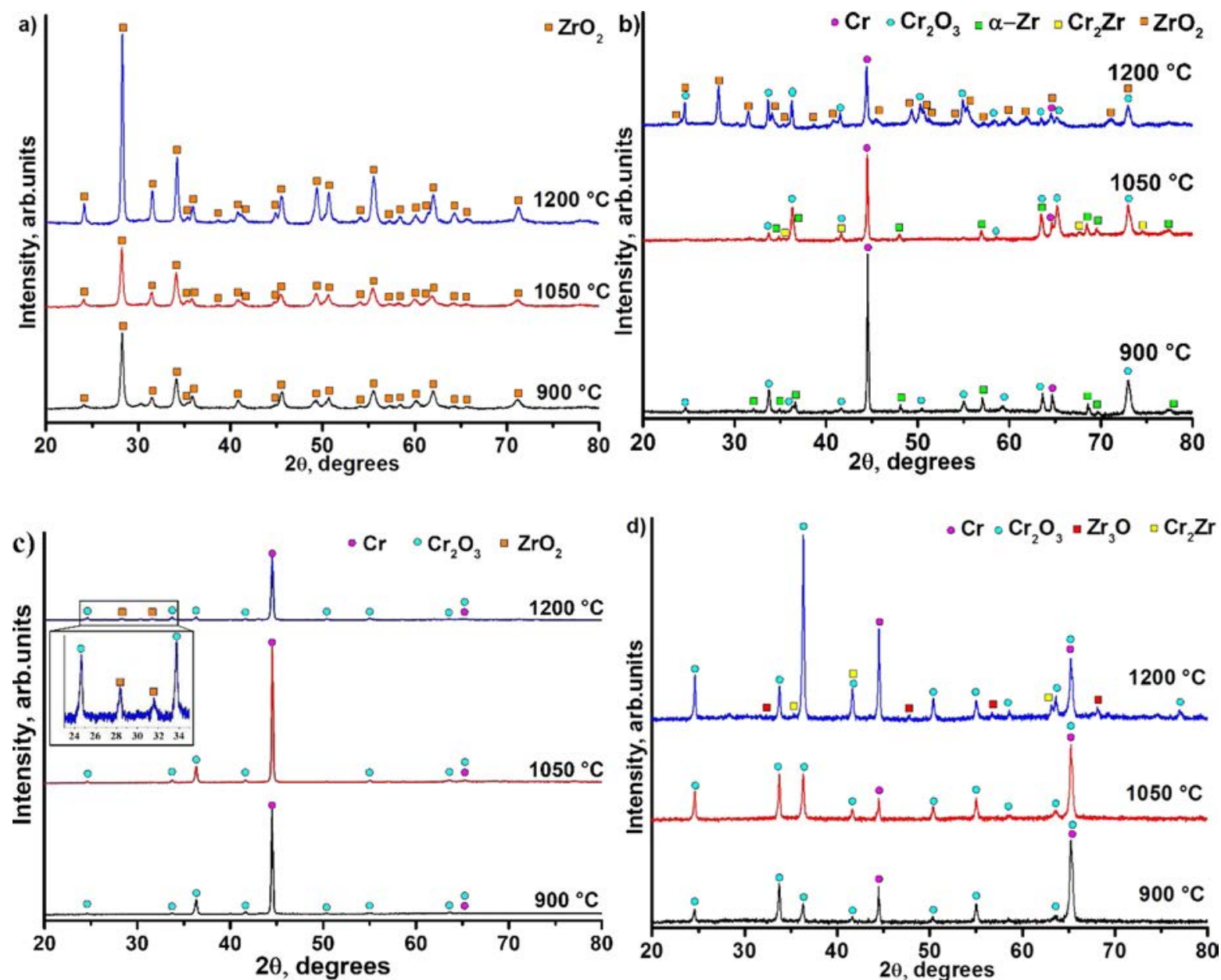

Fig. 5. Diffraction patterns of the samples after the isothermal tests: a - uncoated Zry-4; b - Cr-4.5; c - Cr-6; d - Cr-9.

$9 \mu \mathrm{m}$ thick). Nevertheless, at $1200^{\circ} \mathrm{C}$ the $\mathrm{Cr} 4.5$ sample has the biggest mass gain for $10 \mathrm{~min}$ oxidation $\left(22.90 \mathrm{mg} / \mathrm{cm}^{2}\right)$, whereas the $\mathrm{Zr}$ alloy with thicker $\mathrm{Cr}$ coatings have lower mass gain values of $12.61 \mathrm{mg} / \mathrm{cm}^{2}$ for $\mathrm{Cr} 6$ and $4.13 \mathrm{mg} / \mathrm{cm}^{2}$ for $\mathrm{Cr} 9$ samples.

The XRD patterns and phase composition of the $\mathrm{Cr}$ coated and un coated $\mathrm{Zr}$ alloys after isothermal oxidation at $900-1200^{\circ} \mathrm{C}$ are shown in Fig. 5. Only $\mathrm{ZrO}_{2}$ (monoclinic) phase is formed on the surface of uncoated Zry 4 alloy at the investigated temperatures. For the $\mathrm{Cr} 4.5$ sample, the $\mathrm{Cr}$ (bcc) phase is decreased for $900 \rightarrow 1200^{\circ} \mathrm{C}$, the forma tion of $\mathrm{Cr}_{2} \mathrm{Zr}$ (at $1050^{\circ} \mathrm{C}$ ) and $\mathrm{ZrO}_{2}$ (at $1200^{\circ} \mathrm{C}$ ) phases is observed. The phase composition of $\mathrm{Zr}$ alloys coated by columnar $\mathrm{Cr}$ coatings after oxidation at 900 and $1050{ }^{\circ} \mathrm{C}$ is represented by $\mathrm{Cr}_{2} \mathrm{O}_{3}$ and $\mathrm{Cr}$ phases. The monoclinic $\mathrm{ZrO}_{2}$ phase was detected for the $\mathrm{Cr} 6$ oxidized at $1200^{\circ} \mathrm{C}$, whereas, the sample with thicker $\mathrm{Cr}(9 \mu \mathrm{m})$ coating has only inter diffusion $\mathrm{Cr}_{2} \mathrm{Zr}$ and oxygen stabilized $\alpha \mathrm{Zr}(\mathrm{O})$ phases.

Fig. 6 presents the cross section images of the samples after oxida tion at $1200{ }^{\circ} \mathrm{C}$ for $10 \mathrm{~min}$. The microstructure of the Zry 4 alloy is re presented by the outer $\mathrm{ZrO}_{2}$ layer (more than $190-250 \mu \mathrm{m}$ ) at both sides and the internal oxygen stabilized $\alpha \operatorname{Zr}(\mathrm{O})$ phase (Fig. 6a).

According to the optical microscopy images (Fig. 6b d) and GDOES data (Fig. 7), the $\mathrm{Cr}$ coated $\mathrm{Zr}$ alloy after oxidation has different structure: 


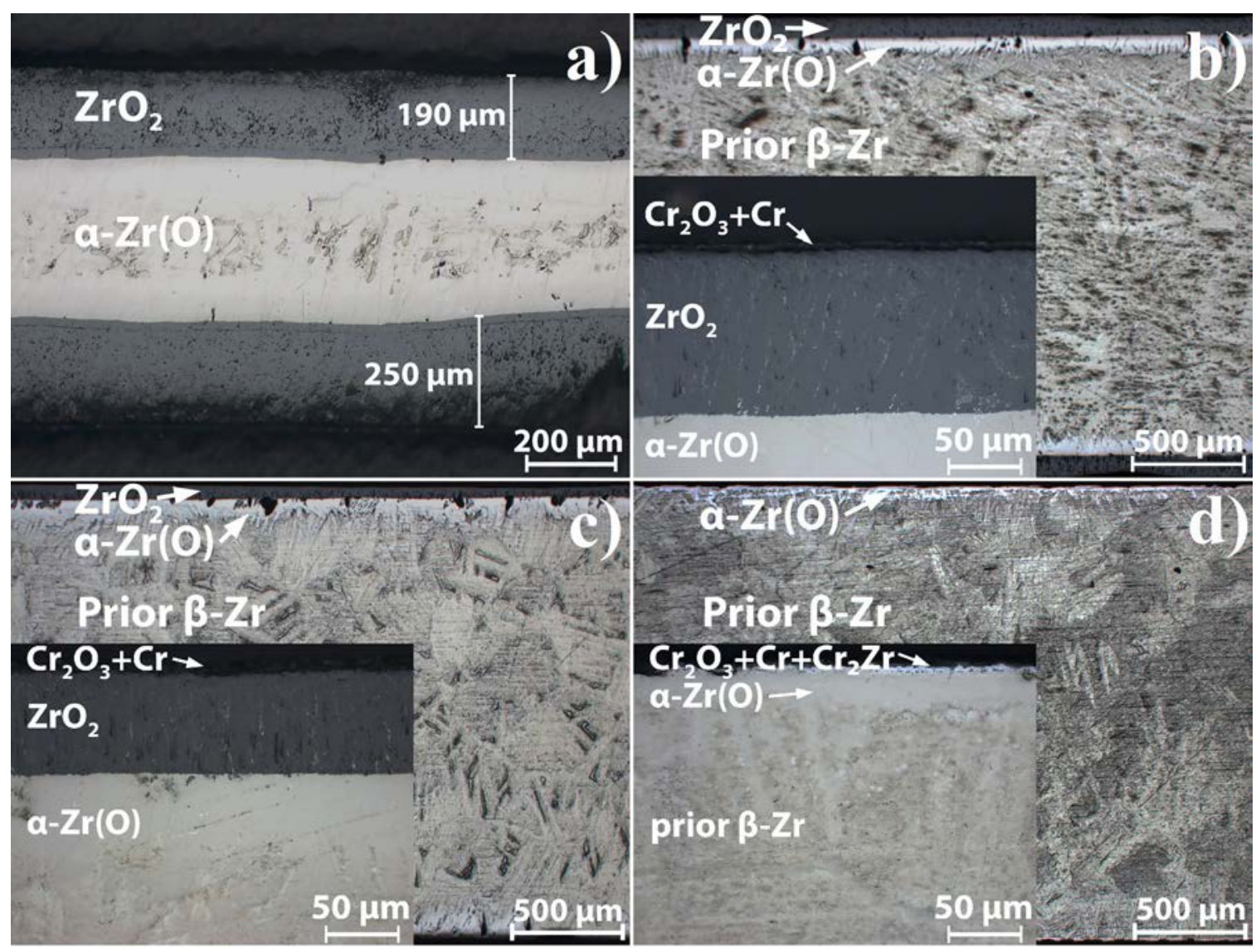

Fig. 6. Optical images of the cross-sections after steam oxidation at $1200{ }^{\circ} \mathrm{C}$ for $10 \mathrm{~min}$ : uncoated $\mathrm{Zry}-4$ (a), $\mathrm{Cr}-4.5$ (b), $\mathrm{Cr}-6$ (c) and $\mathrm{Cr}-9$ (d).

the protective $\mathrm{Cr}_{2} \mathrm{O}_{3}$ layer with residual $\mathrm{Cr}$ (or $\mathrm{Cr}+\mathrm{ZrO}_{2}$ );

the $\mathrm{Cr}_{2} \mathrm{Zr}$ inter diffusion layer (only for $\mathrm{Cr}$ 9);

the $\mathrm{ZrO}_{2}$ layer with the thickness of 85110 and $50-70 \mu \mathrm{m}$ for $\mathrm{Cr}$ 4.5 and $\mathrm{Cr} 6$;

oxygen stabilized $\alpha \operatorname{Zr}(\mathrm{O})$ phase with non uniform thickness; the internal prior $\beta \mathrm{Zr}$ phase.

The profiles reveal oxidation of $\mathrm{Cr}$ coated alloy and noticeable inter diffusion of $\mathrm{Cr}$ and $\mathrm{Zr}$ at the coating/alloy interface. Depending on the coating type, the formation of different multilayer structures was found. So, the $\mathrm{Cr} 4.5$ and $\mathrm{Cr} 6$ samples have similar elemental distribution over the sputtering depth of $20 \mu \mathrm{m}$ : outer chromia $(1.92 .4 \mu \mathrm{m}) \rightarrow$ residual Cr with $\mathrm{ZrO}_{2}$ grains (up to $\sim 6 \mu \mathrm{m}$ ) $\rightarrow$ thick $\mathrm{ZrO}_{2}$ layer (Fig. $7 \mathrm{a}$ and b). Most likely the growth of zirconium oxide phase in the residual $\mathrm{Cr}$ is caused by the oxidation of earlier formed $\mathrm{Cr}_{2} \mathrm{Zr}$ phase in high inward oxygen flux (see Eq. (2) in [10]).

GDOES and SEM observations show that $\mathrm{Cr} 9$ is fully protective at $1200{ }^{\circ} \mathrm{C}$ for $10 \mathrm{~min}$, no $\mathrm{ZrO}_{2}$ layers are found at both sides of the sample (Fig. $7 \mathrm{c})$. There is the protective $\mathrm{Cr}_{2} \mathrm{O}_{3}$ layer $(\sim 3.5 \mu \mathrm{m})$ at the surface, residual $\mathrm{Cr}$ (up to $5.5 \mu \mathrm{m}$ ), non uniform inter diffusion $\mathrm{Cr} \mathrm{Zr}$ layer, $\alpha \mathrm{Zr}$ (O) layer with the thickness of $\sim 15-30 \mu \mathrm{m}$. Under these oxidation conditions, the $\mathrm{Cr}_{2} \mathrm{Zr}$ layer has $1.92 .7 \mu \mathrm{m}$ thickness that well correlates with the recent studies $[9,12,34]$. The importance of coating thickness and microstructure at high temperatures is also evidenced by several possible processes: $\mathrm{Cr}$ volatilization $[10,16]$ with formation of gaseous species and delamination/cracking of the protective $\mathrm{Cr}_{2} \mathrm{O}_{3}$ layer at the oxide/metal interface. Moreover, the $\mathrm{Cr}_{2} \mathrm{O}_{3}$ layer can be reduced by zirconium due to higher thermodynamic stability of zirconia compared to chromia. In this process $\mathrm{Zr}$ atoms can transfer electrons to $\mathrm{Cr}_{2} \mathrm{O}_{3}$ reducing $\mathrm{Cr}$ ions to neutral atoms and the free oxygen ions can diffuse and react with $\mathrm{Zr}^{4+}$ to form $\mathrm{ZrO}_{2}$ phase [10,35]. These mechanisms are also supported by changes of phase composition with temperature rise by XRD and SEM in this study.

\section{Discussion}

The multi cathode magnetron with "closed" magnetic field config uration has low deposition rate $(\sim 6 \mathrm{~nm} / \mathrm{s})$ and high energy flux to substrate, so it can produce the dense $\mathrm{Cr}$ coatings. Contrary, the mag netron with hot target can be used for high rate $\mathrm{Cr}$ deposition $(\sim 50 \mathrm{~nm} / \mathrm{s})$, but the deposited coatings have porous and columnar microstructure due to low energy flux to substrate. Both constructions of magnetron sputtering systems were used for deposition of the $\mathrm{Cr}$ (4.5 $9.0 \mu \mathrm{m}$ thick) coatings with dense or columnar microstructure onto E110 alloy. The presented results show that microstructure and coating thickness significantly affect the oxidation kinetics of $\mathrm{Cr}$ coated zirconium alloy in water steam in the temperature range $900-1200^{\circ} \mathrm{C}$. To evaluate this phenomenon, Arrhenius plots were constructed based on the data of linear approximation of continuous oxidation process at 900 and $1050^{\circ} \mathrm{C}$ (Fig. 8). For $1200^{\circ} \mathrm{C}$, the linear approximation of the experimental data was carried out before the transition period, which characterizes the oxidation process of $\mathrm{Cr}$ coating. The linear curves of $\mathrm{ln}$ $\left(R_{t}\right)$ vs. $(1 / T)$ for the $\mathrm{Cr}$ coated $\mathrm{Zr}$ alloy are fitted according to the $\mathrm{Ar}$ rhenius equation:

$K_{t}=A \cdot \exp \left(E_{a} / R \cdot T\right)$,

where $A$ the pre exponential constant; $E_{a}$ the activation energy for oxidation process; $R$ the gas constant $(8.31 \mathrm{~J} / \mathrm{mol} \cdot \mathrm{K}) ; T$ the tem perature $(\mathrm{K})$.

The $\mathrm{Zr}$ alloy coated by the dense $\mathrm{Cr}$ film ( $\mathrm{Cr} 4.5)$ has significantly higher activation energy $(202 \mathrm{~kJ} / \mathrm{mol})$ compared to the samples with the columnar (177-183 kJ/mol) coatings, which confirms its better protective properties during steam oxidation. However, higher value of $A\left(3.4 \cdot 10^{7}\right)$ for the $\mathrm{Cr} 4.5$ indicates the decrease of corrosion resistance 

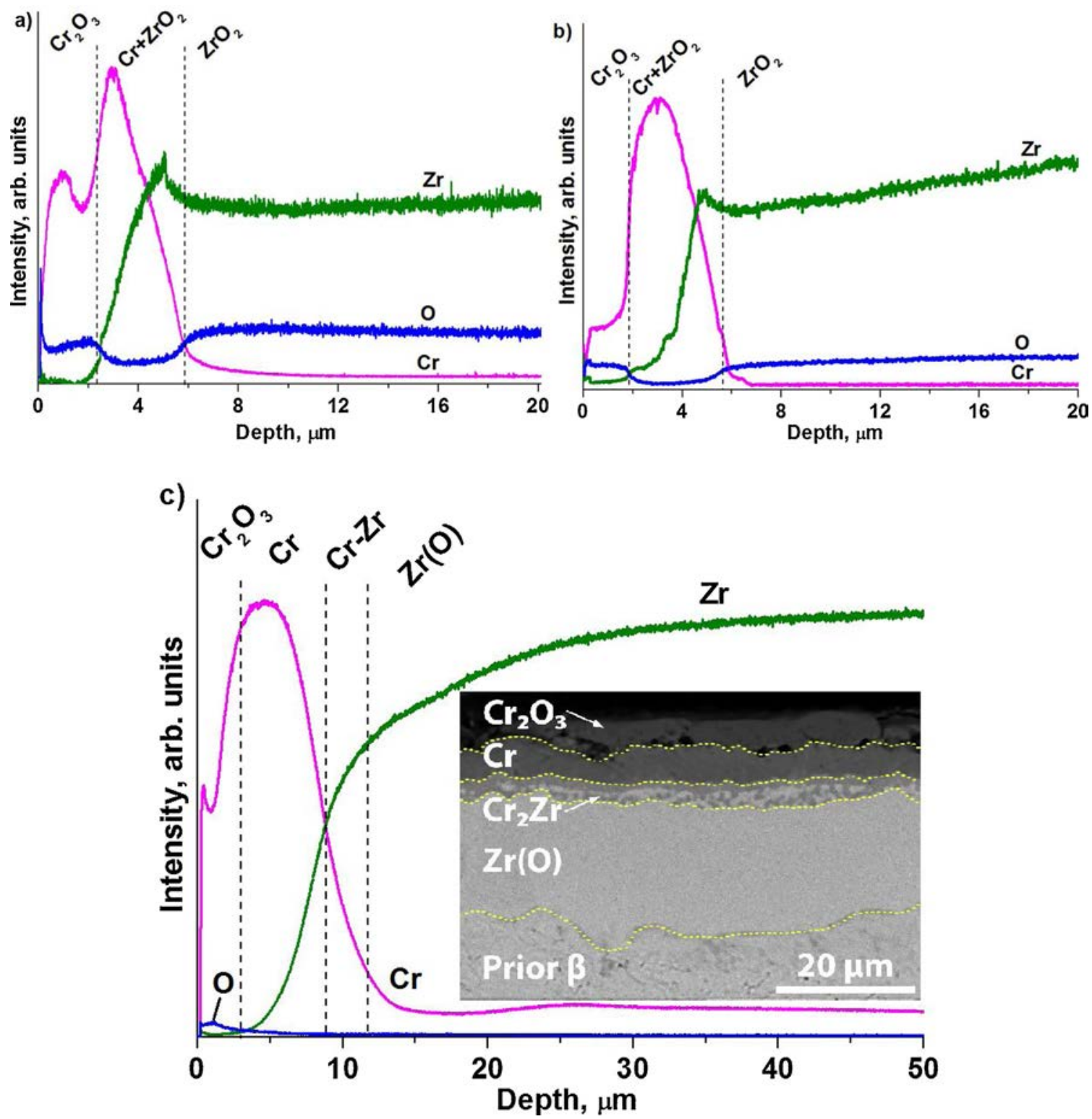

Fig. 7. GDOES depth distribution profiles of elements in the $\mathrm{Cr}$-coated $\mathrm{Zr}$ samples after oxidation at $1200{ }^{\circ} \mathrm{C}$ for $10 \mathrm{~min}$ : $\mathrm{Cr}-4.5$ (a), $\mathrm{Cr}-6$ (b) and $\mathrm{Cr}-9$ (c). Inset: crosssection SEM image of the oxidized Cr-9 sample.

concerning to the samples with thicker coatings $\left(\mathrm{Cr} 6 \quad 4.0 \cdot 10^{6}\right.$; $\mathrm{Cr} 9$ $2.9 \cdot 10^{6}$ ) at higher oxidation temperature. The obtained activation en ergy for the dense $\mathrm{Cr}$ coating is comparable or higher than the values reported for $\mathrm{Cr}$ coated zirconium alloy [10] and pure bulk chromium in air or oxygen [36 38], but slightly lower than for CrN coated Zr [39]. Even if the order of magnitude seems to be consistent with some lit erature data, one should be cautious about the "physical meaning" of the apparent activation energy derived from the overall weight gain evolutions due to potential effects of some experimental bias (tem perature overshoot and contribution of unprotected sample areas).

At low temperatures, the oxidation of $\mathrm{Cr}$ coatings is only expected: no $\mathrm{ZrO}_{2}$ phase in the alloy can be detected after oxidation at $900{ }^{\circ} \mathrm{C}$ (30 $\mathrm{min})$ and $1050^{\circ} \mathrm{C}(20 \mathrm{~min})$. Under these conditions, the mass gain is extremely low $\left(0.31-1.64 \mathrm{mg} / \mathrm{cm}^{2}\right)$, whereas it should be $\geq 4-7 \mathrm{mg}$ / $\mathrm{cm}^{2}$ [9 11,27] to form $\mathrm{ZrO}_{2}$ layer beneath the $1-10 \mu \mathrm{m}$ thick $\mathrm{Cr}$ coatings. Thus, the low mass gain of the samples is caused by the for mation of the protective $\mathrm{Cr}_{2} \mathrm{O}_{3}$ layer on coating surface that has a strong oxidation resistance in steam up to $1100^{\circ} \mathrm{C}$ [40]. Nevertheless, the different oxidation kinetics of the $\mathrm{Cr}$ coatings is observed depending on their microstructure. The initial stage of oxidation for columnar coatings is accompanied by a rapid weight gain, while for the dense coating it is changed gradually (Figs. 3 and 4). This behavior is at tributed to grain boundary oxygen diffusion until the external protec tive chromia layer is formed. Thus, the growth of the oxide layer in the dense $\mathrm{Cr}$ coating occurs with lower rates. It results the lowest oxidation kinetics of the dense $\mathrm{Cr} 4.5$ compared to columnar ones. Next, the continuous oxidation of the residual $\mathrm{Cr}$ can be accompanied by $\mathrm{Cr}_{2} \mathrm{O}_{3}$ growth and formation of $\mathrm{Cr}_{2} \mathrm{Zr}$ interlayer beneath the residual $\mathrm{Cr}$. For columnar coatings, $\alpha \mathrm{Zr}(\mathrm{O})$ can also be formed due to oxygen diffusion along grain boundaries. Thus, at this temperature range, the dense $\mathrm{Cr}$ coating has higher oxidation resistance even with a thinner $\mathrm{Cr}_{2} \mathrm{O}_{3}$ layer $\left(900{ }^{\circ} \mathrm{C} \quad 0.31 \mathrm{mg} / \mathrm{cm}^{2}\right.$ ). Oppositely, the columnar $\mathrm{Cr}$ coatings can be oxidized for higher depth in view of their porous microstructure $(0.49$ and $0.57 \mathrm{mg} / \mathrm{cm}^{2}$ ).

The oxidation of $\mathrm{Cr}$ coated $\mathrm{Zr}$ alloy is accelerated with temperature rise. This is clearly seen from the balancing of mass gains at the tran sient tests at $1100{ }^{\circ} \mathrm{C}\left(\sim 0.86 \mathrm{mg} / \mathrm{cm}^{2}\right)$ and increase of mass gain for isothermal test at $1050{ }^{\circ} \mathrm{C}$. This means the rise of oxygen diffusion through the protective layer to a residual $\mathrm{Cr}$ and, deeper, in the $\mathrm{Zr}$ alloy. There are several processes that should be mentioned: 


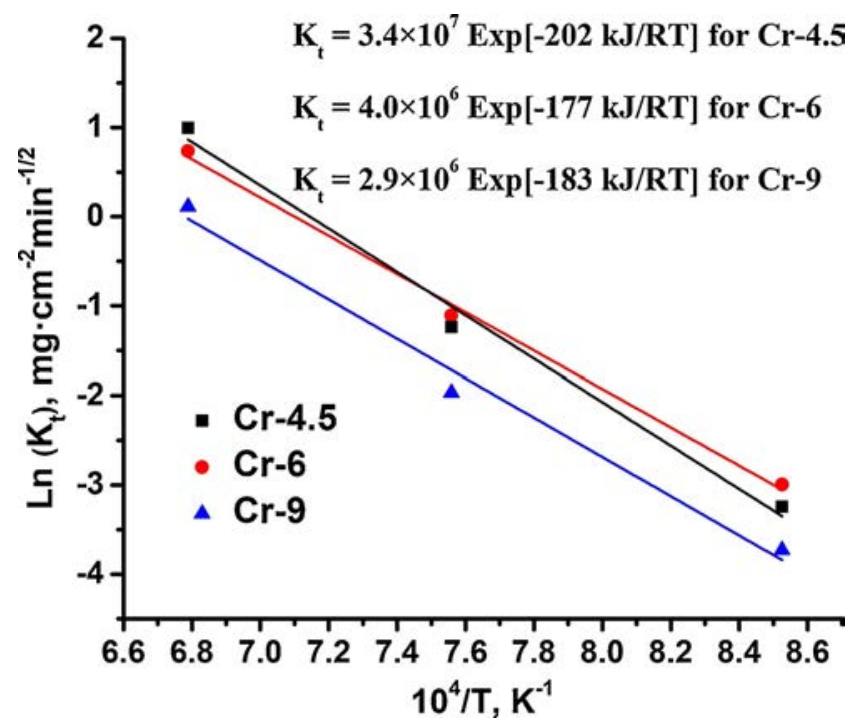

Fig. 8. The Arrhenius plots for Cr-coated $\mathrm{Zr}$ alloy in a steam.

the inter diffusion of $\mathrm{Cr}$ and $\mathrm{Zr}$ due to high diffusion coefficient of $\mathrm{Cr}$ into $\beta \mathrm{Zr}$ phase [41] and growth of $\mathrm{Cr}_{2} \mathrm{Zr}$ phase that is found by XRD for the sample with thinner $\mathrm{Cr}$ coating even for $1050{ }^{\circ} \mathrm{C}$; the formation of Kirkendall cavities at the $\mathrm{Cr}_{2} \mathrm{O}_{3} / \mathrm{Cr}$ and $\mathrm{Cr} \mathrm{Zr}$ in terfaces [10];

shorter diffusion path of $\mathrm{O}$ to the $\mathrm{Zr}$ alloy through thinner protective coating.

The inter diffusion of $\mathrm{Cr}$ and $\mathrm{Zr}$ becomes more significant during oxidation at $1200{ }^{\circ} \mathrm{C}$, with higher diffusion coefficients for $\mathrm{Cr}$ into $\mathrm{Zr}$. The influence of coating thickness and $\mathrm{Cr} \mathrm{Zr}$ interlayer on oxidation kinetics of $\mathrm{Cr}$ coated $\mathrm{Zr}$ alloy can be demonstrated by the different evolution of mass gains at $1200^{\circ} \mathrm{C}$ (Fig. 4).

The $\mathrm{Cr} 9$ sample remains fully protective during $10 \mathrm{~min}$ exposure at $1200{ }^{\circ} \mathrm{C}\left(4.13 \mathrm{mg} / \mathrm{cm}^{2}\right)$, no $\mathrm{ZrO}_{2}$ phase is found beneath the $\mathrm{Cr} \mathrm{Zr}$ in terlayer. The transition region with the accelerated oxidation is ob served for the $\mathrm{Cr} 6$ sample. This corresponds to degradation of pro tective properties of $6 \mu \mathrm{m}$ thick $\mathrm{Cr}$ coating, i.e. transition from protective to non protective scale. Brachet et al. [10] showed that the new oxidation mechanism of $\mathrm{Cr}$ coated $\mathrm{Zr}$ alloy can be activated at this stage. The latter is associated with outward diffusion of zirconium re sulting nucleation of zirconia stringers at the $\mathrm{Cr}$ grain boundaries, which promotes the diffusion of oxygen anions through the coating (zirconia networks).

The relatively thin coated $\mathrm{Cr} 4.5$ sample shows poor protective properties under steam oxidation at $1200{ }^{\circ} \mathrm{C}\left(22.9 \mathrm{mg} / \mathrm{cm}^{2}\right)$. Due to lower coating thickness $(4.5 \mu \mathrm{m})$ and fast inter diffusion of $\mathrm{Cr}$ and $\mathrm{Zr}$ at high temperatures, the oxygen diffusion path is strongly decreased and the coating can be protective only for a short oxidation period $(\sim 2 \mathrm{~min}$, see Fig. 4c). It results in the formation of thick $(\sim 70-110 \mu \mathrm{m})$ zirconia layer beneath the oxidized coating (Fig. 6b). Therefore, the overall oxidation kinetics of the $\mathrm{Cr} 4.5$ sample is mainly defined by $\mathrm{Zr}$ substrate oxidation (non protective oxide scale).

Therefore, based on the described results, we suggest several aspects in oxidation of the $\mathrm{Cr}$ coated $\mathrm{Zr}$ alloy. As long as the $\mathrm{Cr}$ coating is still protective, the microstructure of the $\mathrm{Cr}$ layer strongly affects the oxi dation kinetics of the $\mathrm{Cr}$ coated $\mathrm{Zr}$ alloy. The time until transition from protective to non protective behavior at high temperatures is mainly determined by the thickness of $\mathrm{Cr}$ layer. However, dense microstructure of protective coatings is desirable to prevent the formation of brittle $\alpha$ $\mathrm{Zr}(\mathrm{O})$ layer due to oxygen diffusion through the columnar grain boundaries. For higher temperatures $\left(1100-1200^{\circ} \mathrm{C}\right)$ or longer oxi dation time, fast inter diffusion of $\mathrm{Cr}$ and $\mathrm{Zr}$ with formation of $\mathrm{Cr}_{2} \mathrm{Zr}$ phase becomes more important in oxidation kinetics.

\section{Conclusions}

For the oxidation temperature range of $900-1200^{\circ} \mathrm{C}$, the $\mathrm{Cr}$ coat ings deposited by magnetron sputtering onto zirconium alloy can be a fully protective in steam environment. Their oxidation kinetics for $10-30 \mathrm{~min}$ was studied as a function of coating microstructure and thickness. The main conclusions are the following.

1 As long as the $\mathrm{Cr}$ coating is intact/protective, which is given up to $1100^{\circ} \mathrm{C}$ for reasonable times relevant for LOCA scenarios, the mi crostructure of the $\mathrm{Cr}$ coatings is a key characteristic in accident conditions. The results show that a dense $4.5 \mu \mathrm{m}$ thick $\mathrm{Cr}$ coating with higher activation energy $(202 \mathrm{~kJ} / \mathrm{mol})$ provides better oxida tion resistance up to $1100{ }^{\circ} \mathrm{C}$ compared to thicker ( 6 and $\left.9 \mu \mathrm{m}\right)$ co lumnar coatings $(177-183 \mathrm{~kJ} / \mathrm{mol})$.

2 An accelerated oxidation kinetics of $\mathrm{Cr}$ coated $\mathrm{Zr}$ alloy is observed after transition from protective to non protective behavior. The duration of protective period is mainly dependent on the coating thickness. Thicker protective coatings have longer diffusion path of $\mathrm{O}$ to the $\mathrm{Zr}$ alloy in the conditions of $\mathrm{Cr}$ consumption by $\mathrm{Cr} \mathrm{Zr}$ inter diffusion. The $9 \mu \mathrm{m}$ thick columnar $\mathrm{Cr}$ coating fully protects the E110 alloy from oxidation at $1200^{\circ} \mathrm{C}$ for $10 \mathrm{~min}$, while the 4.5 $6.0 \mu \mathrm{m}$ thick $\mathrm{Cr}$ coatings does not at the same oxidation condi tions.

3 The fast inter diffusion of $\mathrm{Cr}$ and $\mathrm{Zr}$ with $\mathrm{Cr}_{2} \mathrm{Zr}$ formation at the coating/alloy interface at higher temperatures $\left(>1100^{\circ} \mathrm{C}\right)$ and for longer oxidation time can significantly decrease the protective properties of the $\mathrm{Cr}$ coatings. These aspects cause poor efficiency of $\mathrm{Cr}$ coatings with low thickness for $\mathrm{Zr}$ fuel claddings at LOCA con ditions.

\section{CRediT authorship contribution statement}

E.B. Kashkarov: Conceptualization, Investigation, Formal analysis, Writing original draft. D.V. Sidelev: Data curation, Methodology, Investigation, Writing review \& editing. M.S. Syrtanov: Investigation, Visualization. C. Tang: Investigation, Writing review \& editing. M. Steinbrück: Validation, Resources, Writing review \& editing.

\section{Declaration of Competing Interest}

The authors declare that there are no conflicts of interest.

\section{Acknowledgements}

The authors are grateful to C. Miton for performing majority of the oxidation experiments. The authors also acknowledge Tomsk Polytechnic University Enhancement Program.

\section{References}

[1] C. Tang, M. Stueber, H.J. Seifert, M. Steinbrueck, Protective coatings on zirconiumbased alloys as accident-tolerant fuel (ATF) claddings, Corros. Rev. 35 (2017) 141-165, https://doi.org/10.1515/corrrev-2017-0010. 
[2] Z. Duan, H. Yang, Y. Satoh, K. Murakami, S. Kano, Z. Zhao, J. Shen, H. Abe, Current status of materials development of nuclear fuel cladding tubes for light water reactors, Nucl. Energy Des. 316 (2017) 131-150, https://doi.org/10.1016/j. nucengdes.2017.02.031.

[3] M. Wagih, B. Spencer, J. Hales, K. Shirvan, Fuel performance of chromium-coated zirconium alloy and silicon carbide accident tolerant fuel claddings, Ann. Nucl. Energy 120 (2018) 304-318, https://doi.org/10.1016/j.anucene.2018.06.001.

[4] J.C. Brachet, M.L. Saux, M.L. Flem, S. Urvoy, E. Rouesne, T. Guilbert, et al., Ongoing studies at CEA on chromium coated zirconium based nuclear fuel claddings for enhanced accident tolerant LWRs fuel, Proc. 2015 LWR Fuel Perform/TopFuel (2015) 31-38.

[5] K.A. Terrani, Accident tolerant fuel cladding development: promise, status, and challenges, J. Nucl. Mater. 501 (2018) 13-30, https://doi.org/10.1016/j.jnucmat. 2017.12.043.

[6] M. Huang, Y. Li, G. Ran, Z. Yang, P. Wang, Cr-coated Zr-4 alloy prepared by electroplating and its in situ $\mathrm{He}^{+}$irradiation behavior, J. Nucl. Mater. 538 (2020) 152240, , https://doi.org/10.1016/j.jnucmat.2020.152240.

[7] J. Bischoff, C. Delafoy, C. Vauglin, P. Barberis, C. Roubeyrie, D. Perche, et al., AREVA NP's enhanced accident-tolerant fuel developments: focus on Cr-coated M5 cladding, Nucl. Eng. Technol. 50 (2018) 223-228, https://doi.org/10.1016/j.net. 2017.12.004.

[8] J.C. Brachet, T. Guilbert, M. Lesaux, J. Rousselot, G. Nony, et al., Behavior of CrCoated M5 Claddings During and After High Temperature Steam Oxidation From 800 C up to 1500 C. Topfuel 2018, Sep 2018, Prague, Czech Republic, ffcea02328975 (2018)

[9] E.B. Kashkarov, D.V. Sidelev, M. Rombaeva, M.S. Syrtanov, G.A. Bleykher, Chromium coatings deposited by cooled and hot target magnetron sputtering for accident tolerant nuclear fuel claddings, Surf. Coat. Technol. 389 (2020) 125618, , https://doi.org/10.1016/j.surfcoat.2020.125618

[10] J.C. Brachet, E. Rouesne, J. Ribis, T. Guilbert, S. Urvoy, G. Nony, et al., High temperature steam oxidation of chromium-coated zirconium-based alloys: kinetics and process, Corros. Sci. 167 (2020) 108537, , https://doi.org/10.1016/j.corsci. 2020.108537

[11] J.C. Brachet, I. Idarraga-Trujillo, M. Le Flem, M. Le Saux, V. Vandenberghe, et al., Early studies on Cr-coated Zircaloy-4 as enhanced accident tolerant nuclear fuel claddings for light water reactors, J. Nucl. Mater. 517 (2019) 268-285, https://doi. org/10.1016/j.jnucmat.2019.02.018.

[12] J. Krejcí, J. Kabátová, F. Manoch, J. Kočí, L. Cvrček, J. Málek, et al., Development and testing of multicomponent fuel cladding with enhanced accidental performance, Nucl. Eng. Technol. 52 (2020) 597-609, https://doi.org/10.1016/j.net. 2019.08.015

[13] W. Xiao, H. Chen, X. Liu, D. Tang, H. Deng, S. Zou, Y. Ren, X. Zhou, M. Lei, Thermal shock resistance of TiN-, Cr-, and TiN/Cr-coated zirconium alloy, J. Nucl. Mater. 526 (2019) 151777, , https://doi.org/10.1016/j.jnucmat.2019.151777.

[14] M. Sevecek, A. Gurgen, A. Seshadri, Y. Che, M. Wagih, B. Phillips, V. Champagne, K. Shirvan, Development of $\mathrm{Cr}$ cold spray-coated fuel cladding with enhanced accident tolerance, Nucl. Eng. Technol. 50 (2018) 229-236, https://doi.org/10.1016/ j.net.2017.12.011.

[15] A.S. Kuprin, V.A. Belous, V.N. Voyevodin, V.V. Bryk, R.L. Vasilenko, V.D. Ovcharenko, E.N. Reshetnyak, G.N. Tolmachova, P.N. V'yugov, Vacuum-arc chromium-based coatings for protection of zirconium alloys from the high-temperature oxidation in air, J. Nucl. Mater. 465 (2015) 400-406, https://doi.org/10. 1016/j.jnucmat.2015.06.016.

[16] H. Yeom, B. Maier, G. Johnson, T. Dabney, M. Lenling, K. Sridharan, High temperature oxidation and microstructural evolution of cold spray chromium coatings on Zircaloy-4 in steam environments, J. Nucl. Mater. 526 (2019) 151737, , https:// doi.org/10.1016/j.jnucmat.2019.151737.

[17] Q.S. Chen, C.H. Liu, R.Q. Zhang, H.Y. Yang, T.G. Wei, et al., Microstructure and high-temperature steam oxidation properties of thick $\mathrm{Cr}$ coatings prepared by magnetron sputtering for accident tolerant fuel claddings: the role of bias in the deposition process, Corros. Sci. 162 (2020) 108378, , https://doi.org/10.1016/j. corsci.2019.108378.

[18] G. Bräuer, B. Szyszka, M. Vergöhl, R. Bandorf, Magnetron sputtering - milestones of 30 years, Vacuum 84 (2010) 1354-1359, https://doi.org/10.1016/j.vacuum.2009. 12.014

[19] M. Zaidabadi, G.R. Ansarifar, M.H. Esteki, Thermal hydraulic analysis of VVER1000 nuclear reactor with dual-cooled annular fuel using K- $\omega$ SST Turbulence model, Ann. Nucl. Energy 101 (2017) 118-127, https://doi.org/10.1016/j. anucene.2016.09.027.

20] D.V. Sidelev, G.A. Bleykher, V.P. Krivobokov, Z. Koishybayeva, High-rate magnetron sputtering with hot target, Surf. Coat. Technol. 308 (2016) 168-173, https:// doi.org/10.1016/j.surfcoat.2016.06.096.

[21] A.V. Tumarkin, A.V. Kaziev, D.V. Kolodko, A.A. Pisarev, M.M. Kharkov, G.V. Khodachenko, Deposition of copper coatings in a magnetron with liquid target, Phys. Atom. Nucl. 78 (2015) 1674-1676, https://doi.org/10.1134/ S1063778815140136.

[22] J. Vlcek, B. Zustin, J. Rezek, K. Burcalova, J. Tesar, Pulsed magnetron sputtering of metallic films using a hot target, 52nd Annual Technical Conference Proceedings of the Society of Vacuum Coaters, Santa Clara, 2009, pp. 219-223.

[23] J. Musil, M. Jaroš, R. Čerstvý, S. Haviar, Evolution of microstructure and macrostress in sputtered hard Ti(Al,V)N films with increasing energy delivered during their growth by bombarding ions, J. Vac. Sci. Technol. A 35 (2017) 020601, , https://doi. org/10.1116/1.4967935.

[24] J. Musil, Flexible hard nanocomposite coatings, RSC Adv. 5 (2015) 60482-60495.

[25] D.V. Sidelev, G.A. Bleykher, M. Bestetti, V.P. Krivobokov, A. Vicenzo, S. Franz, M.F. Brunella, A comparative study on the properties of chromium coatings deposited by magnetron sputtering with hot and cooled target, Vacuum 143 (2017) 479-485, https://doi.org/10.1016/j.vacuum.2017.03.020.

[26] H. Kersten, H. Deutsch, H. Steffen, G.M.W. Kroesen, R. Hippler, The energy balance at substrate surfaces during plasma processing, Vacuum 63 (2001) 385-431, https://doi.org/10.1016/S0042-207X(01)00350-5.

[27] D.V. Sidelev, E.B. Kashkarov, M.S. Syrtanov, V.P. Krivobokov, Nickel-chromium (Ni-Cr) coatings deposited by magnetron sputtering for accident tolerant nuclear fuel claddings, Surf. Coat. Technol. 369 (2019) 69-78, https://doi.org/10.1016/j. surfcoat.2019.04.057.

[28] I. Efeoglu, R.D. Arnell, S.F. Tinston, D.G. Teer, The mechanical and tribological properties of titanium aluminum nitride coatings formed in a four magnetron closed-field sputtering system, Surf. Coat. Technol. 57 (1993) 117-121, https://doi. org/10.1016/0257-8972(93)90027-L.

[29] D.A. Golosov, Balanced magnetic field in magnetron sputtering systems, Vacuum 139 (2017) 109-116, https://doi.org/10.1016/j.vacuum.2017.02.018.

[30] J.A. Thornton, Influence of apparatus geometry and deposition conditions on the structure and topography of thick sputtered coatings, J. Vac. Sci. Technol. 11 (1974) 666-670, https://doi.org/10.1116/1.1312732.

[31] A. Anders, A structure zone diagram including plasma-based deposition and ion etching, Thin Solid Films 518 (2010) 4087-4090, https://doi.org/10.1016/j.tsf. 2009.10.145.

[32] J.V. Cathcart, R.E. Pawel, R.A. McKee, R.E. Druscel, G.J. Yurek, J.J. Cambell, S.H. Jury, Zirconium Metal-Water Oxidation Kinetics IV. Reaction Rate Studies, ORNL/NUREG-17, Aug. (1977).

[33] M.L. Saux, J.C. Brachet, V. Vandenberghe, E. Rouesne, S. Urvoy, A. Ambard, R. Chosson, Effect of a pre-oxide on the high temperature steam oxidation of Zircaloy-4 and M5Framatome alloys, J. Nucl. Mater. 518 (2019) 386-399, https:// doi.org/10.1016/j.jnucmat.2019.03.023.

[34] J.G. Gigax, M. Kennas, H. Kim, B.R. Maier, H. Yeom, G.O. Johnson, K. Sridharan, L. Shao, Interface reactions and mechanical properties of FeCrAl-coated Zircaloy-4, J. Nucl. Mater. 519 (2019) 57-63, https://doi.org/10.1016/j.jnucmat.2019.03.004.

[35] X. Han, J. Xue, S. Peng, H. Zhang, An interesting oxidation phenomenon of $\mathrm{Cr}$ coatings on Zry-4 substrates in high temperature steam environment, Corros. Sci. 156 (2019) 117-124, https://doi.org/10.1016/j.corsci.2019.05.017.

[36] K. Taneichi, T. Narushima, Y. Iguchi, C. Ouchi, Oxidation or nitridation behavior of pure chromium and chromium alloys containing 10 mass $\% \mathrm{Ni}$ or $\mathrm{Fe}$ in atmospheric heating, Mater. Trans. 47 (2006) 2540-2546, https://doi.org/10.2320/matertrans. 47.2540.

[37] E.A. Gulbransen, K.F. Andrew, A preliminary study of the oxidation and vapo pressure of chromium, J. Electrochem. Soc. 99 (1952) 402.

[38] P. Kofstad, K.P. Lillerud, On high temperature oxidation of chromium: II. Properties of $\mathrm{Cr}_{2} \mathrm{O}_{3}$ and the oxidation mechanism of chromium, J. Electrochem. Soc. 127 (1980) 2410-2419.

[39] C. Meng, L. Yang, Y. Wu, J. Tan, W. Dang, X. He, X. Ma, Study of the oxidation behavior of CrN coating on Zr alloy in air, J. Nucl. Mater. 515 (2019) 354-369, https://doi.org/10.1016/j.jnucmat.2019.01.006.

[40] D.J. Young, High Temperature Oxidation and Corrosion of Metals / Oxford, Elsevier, UK, 2008 - 573 pp.

[41] R.A. Perez, H. Nakajima, F. Dyment, Diffusion in -Ti and Zr, Mater. Trans. 44 (2003) 2-13, https://doi.org/10.2320/matertrans.44.2. 
Karlsruher Institut für Technologie

\section{Repository KITopen}

Dies ist ein Postprint/begutachtetes Manuskript.

Empfohlene Zitierung:

Kashkarov, E. B.; Sidelev, D. V.; Syrtanov, M. S.; Tang, C.; Steinbrück, M.

Oxidation kinetics of Cr-coated zirconium alloy: Effect of coating thickness and microstructure.

2020. Corrosion science, 175.

doi: $10.5445 / / R / 1000122959$

Zitierung der Originalveröffentlichung:

Kashkarov, E. B.; Sidelev, D. V.; Syrtanov, M. S.; Tang, C.; Steinbrück, M.

Oxidation kinetics of $\mathrm{Cr}$-coated zirconium alloy: Effect of coating thickness and microstructure.

2020. Corrosion science, 175, 108883.

doi:10.1016/j.corsci.2020.108883 